\title{
Chemical Composition and Antibacterial Potential of Artemisia arborescens L. Essential Oil
}

\author{
M. Militello • L. Settanni - A. Aleo • \\ C. Mammina - G. Moschetti - G. M. Giammanco • \\ M. Amparo Blàzquez $\cdot$ A. Carrubba
}

Received: 3 November 2010/Accepted: 17 December 2010/Published online: 25 December 2010

(C) Springer Science+Business Media, LLC 2010

\begin{abstract}
This study was undertaken to characterize the essential oil (EO) of Artemisia arborescens growing wild in Sicily. EO, extracted by steam distillation, was examined for its chemical composition and for its capability to inhibit some food-borne pathogen bacteria. A total of 43 compounds (13 monoterpene hydrocarbons, 14 oxygenated monoterpenes, 10 sesquiterpene hydrocarbons, three oxygenated sesquiterpenes and less amount of other three compounds), which account $93.73 \%$ of the total oil, were identified by gas chromatography and gas chromatography-mass spectrometry. Oxygenated monoterpenes (57.32\%) constituted the main fraction, with $\beta$-thujone as the main compound $(45.04 \%)$, followed by the sesquiterpene hydrocarbon chamazulene $(22.71 \%)$. Undiluted EO showed a large inhibition spectrum against strains of Listeria monocytogenes (34 out of 44), whilst it was ineffective against enterobacteria and salmonellas. The minimum inhibition concentration (MIC) was evaluated for the two
\end{abstract}

M. Militello · A. Carrubba

Dipartimento di Agronomia Ambientale e Territoriale (DAAT), Facoltà di Agraria, Università di Palermo, Viale delle Scienze, 90128 Palermo, Italy

L. Settanni $(\bowtie) \cdot$ G. Moschetti

SENFIMIZO Department, Section of Phytopathology and Agricultural Microbiology, University of Palermo, Viale delle Scienze 4, 90128 Palermo, Italy

e-mail: luca.settanni@unipa.it

A. Aleo - C. Mammina - G. M. Giammanco Department of Health Promotion Sciences, "G. D'Alessandro" University of Palermo, Palermo, Italy

M. A. Blàzquez

Departamento de Farmacologia, Facultat de Farmàcia, Universitat de València, Avda Vicent Andrés Estellés s/n Burjassot, 46100 Valencia, Spain most sensitive strains (L. monocytogenes 186 and 7BO) at two cellular concentrations $\left(10^{6}\right.$ and $\left.10^{7} \mathrm{CFU} \mathrm{ml}^{-1}\right)$. The lowest MIC $\left(0.625 \mu \mathrm{ml}^{-1}\right.$, dilution of oil with acetone) was found for strain L. monocytogenes 186 at $10^{6}$

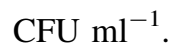

\section{Introduction}

In recent years, consumers have become particularly aware of the health concerns regarding food additives. "Natural" and "traditional" foods, processed without any added chemical preservative, are becoming more and more attractive [42]. When chemical preservatives are used, the low levels used to avoid health implications expose the food-makers to a risk of poor stability and microbial contamination of the final products, since several microorganisms (pathogens and spoilage agents) may acquire a resistance [47]. In particular, the emergence of pathogens, which are resistant to classical preservatives, has determined an urgent necessity for alternative antimicrobial agents.

Several compounds found in plants, which have long been used as natural agents for food preservation [38], are generally well accepted. Amongst these naturally occurring compounds, essential oils (EOs) and extracts of various species of edible and medicinal plants, herbs and spices are considered by the food industry because of their antimicrobial potential. The aptitude of EOs to inhibit the growth of certain microorganisms is of paramount importance, particularly, when it is expressed against food-borne pathogens. Several microorganisms, especially bacteria, are responsible for food-associated diseases. One of the major microbial threats to the food safety in the past two decades is represented by the Gram-positive 
Listeria monocytogenes, which has been recognized as an emerging agent of food-borne diseases [17]. Listeriosis has a very low incidence, but with a high case fatality rate that can exceed $30 \%$ [13]. Recently, several European countries are experiencing an apparently increasing incidence of listeriosis, mainly amongst persons aged 65 years and older [20].

Many spices have been consumed daily by mankind for millennia; they are added to the food matrices mainly to improve their taste and flavour; thus, the consumers are quite used to their presence. For these reasons, EOs from spices represent the natural additives easy to employ in the common applications of food preservation. However, the discovery of new active natural components may generate innovative food preservation strategies. Many examples may be found for plant-derived substances useful as food additives, with a broad spectrum of aptitudes including antioxidant [7, 21] and antimicrobial activities [5, 27]. Those characteristics are due to a number of secondary metabolites that may be found in various parts of the plants, and a strong interest is currently addressed to their individuation and exploitation [8]. So far, the approach applied to the study of herbal ingredients has been generally addressed to the identification of specific molecules (or group of molecules), inside the plant or its utilized part, which are directly responsible of a given (antioxidant, antimicrobial, etc.) action, the so-termed "active principles". As a matter of fact, the biological effect traditionally attributed to a plant-derived material, including EOs, is often due to the occurrence of synergistic and/or antagonistic effects amongst its various components. For food applications, the effectiveness of a specific EO as natural antimicrobial additive is studied considering the EO itself as a whole ingredient, rather than a mixture of components.

Artemisia arborescens (Vaill.) L. is a perennial evergreen woody shrub belonging to the family Asteraceae. The genus Artemisia comprises more than 200 species, and some of them (A. absinthium, A. herba-alba, A. annua and A. vulgaris), which are traditionally used in many areas as medicines, seasoning items or basic ingredients for the manufacturing of liqueurs, have been targeted to many studies concerning their phytochemical features [31]. Many Artemisia species may be found in dry areas of the Northern hemisphere [28]; about 20 species have been detected in Italy, and only five of them grow wild in Sicily [40]. Amongst these, A. arborescens is a strongly smelling, morphologically variable species (or mixture of species), up to $150 \mathrm{~cm}$ height, erect, many-branched, tomentose and whitish, silvery and glabrous in the youngest parts, bearing at flowering time (June-July) many small yellow flowers. Some authors [39] reported that A. arborescens was spread by Moorish invaders and Templar Knights at the time of
Crusades. At present, the species is largely diffused in the Mediterranean area (Italy and North-Africa) and also in the Pacific North America areas.

The scientific interest towards A. arborescens goes back to the past decade. The studies carried out on this species were mainly concerned about its phytochemical characteristics [1, 29, 30, 32, 33, 39], but other aspects have been also considered, such as its genomics [19], its antiviral [43], antioxidant [11], anti-mycoplasmal [3] and allelochemical properties [14]. However, to our knowledge, no studies have been carried out on the antibacterial properties of EOs of this species.

This study is part of a project aimed at characterizing the EO of $A$. arborescens growing wild in Sicily. Based on the above considerations, the objectives of this study were to determine the chemical composition of EO and to evaluate its potential against common food-borne pathogens.

\section{Materials and Methods}

\section{Plant Material and EO Preparation}

Aerial parts of $A$. arborescens L., at the vegetative stage, were collected, in January 2010, from morphologically homogeneous wild populations grown in the North-western area of Sicily (Italy). The fresh plant material was subjected to steam distillation (Estrattore Albrigi LuigiVerona, Italy) for $3 \mathrm{~h}$ to achieve EO.

\section{Gas Chromatography and Mass Spectrometry}

EO was first subjected to capillary gas liquid chromatography (GC) analysis using a Clarus 500GC Perkin-Elmer apparatus equipped with a flame ionization detector (FID), a Hewlett-Packard HP-1 (cross-linked methyl silicone) capillary column (30 m long, $0.2 \mathrm{~mm}$ i.d. with $0.33 \mathrm{~mm}$ film thickness). The column temperature program was $60^{\circ} \mathrm{C}$ for $5 \mathrm{~min}$, with $3^{\circ} \mathrm{C}$ increases per min up to $180^{\circ} \mathrm{C}$, then $20^{\circ} \mathrm{C}$ increases per min up to $280^{\circ} \mathrm{C}$, which was maintained for $10 \mathrm{~min}$. The carrier gas was helium at a flow rate of $1 \mathrm{ml} \mathrm{min}{ }^{-1}$. The FID and injector port temperature were maintained at 250 and $220^{\circ} \mathrm{C}$, respectively.

EO was also analysed by gas chromatography-mass spectrometry (GC-MS) in a Varian Saturn 2000 equipped with a Varian C.S VA-5MS capillary column (30 m long, $0.25 \mathrm{~mm}$ i.d. with $0.25 \mathrm{~mm}$ film thickness). The same working conditions used for GC and split mode injection (ratio 1:25) were employed. Mass spectra were taken over the $m / z, 28-400$ range with an ionizing voltage of $70 \mathrm{eV}$. Kovats retention index (KI) was calculated using co-chromatographed standard hydrocarbons. The individual compounds were identified by MS, and their identity 
was confirmed by comparison of their KIs, relative to $\mathrm{C}_{8}-$ $\mathrm{C}_{32} n$-alkanes, and by comparing their mass spectra and retention times with those of pure substances or with data available in the NIST 98 library and in the literature [2].

\section{Microbial Strains}

The bacterial strains used as indicators (sensitive to EO) for the inhibition assays belong to the culture collection of the Department of Health Promotion Sciences “G. D'Alessandro" (Palermo, Italy) and represent some species generally associated with food-borne diseases. L. monocytogenes, Enterobacter spp. and Salmonella enterica strains were subcultured in Brain Heart Infusion (BHI) agar (Oxoid) and incubated overnight at $37^{\circ} \mathrm{C}$.

\section{Antibacterial Activity Screening}

EO of $A$. arborescens was tested for antibacterial activity applying the paper disc diffusion method [26] with a few modifications. An agar base medium consisting of nutrient agar was overlaid with $7 \mathrm{ml}$ of BHI soft agar $(0.7 \% \mathrm{w} / \mathrm{v})$, previously inoculated with approximately $10^{7} \mathrm{CFU} \mathrm{ml} \mathrm{m}^{-1}$ of a given strain to be tested for sensitivity versus EO. Four sterile filter paper discs (Whatman No. 1) of $6 \mathrm{~mm}$ diameter were placed onto the surface of the double agar layer, at a distance of approximately $3 \mathrm{~cm}$ from one another. Two discs were used as control and soaked with $10 \mu \mathrm{l}$ of sterile water (negative control), or streptomycin [(10\% w/v), positive control], whilst the remaining two discs were both soaked with $10 \mu \mathrm{l}$ of EO. Plates were incubated at $37^{\circ} \mathrm{C}$ for $24 \mathrm{~h}$ and the inhibitory activity was evaluated as positive if a definite clear area was detected around the paper disc.

\section{Determination of Minimum Inhibitory Concentration}

The antibacterial activity of EO was measured as minimum inhibitory concentration (MIC), which represents the most common expression of EO antibacterial performances [5]. MIC is defined as the lowest concentration of an active compound inhibiting visible growth of test organisms [25]. In brief, a given EO is serially diluted (dilution factor $=2$ ) using an organic solvent and all dilutions are tested against the sensitive strains.

The strains showing the highest sensitivity to the screening assay were used for MIC calculation. The EO was diluted in acetone, added to BHI broth medium and tested employing the sensitive strains at two different final cell concentrations $\left(10^{7}\right.$ and $\left.10^{6} \mathrm{CFU} \mathrm{ml}^{-1}\right)$, in order to evaluate the effect of the number of cells on the sensitivity of the species. Acetone alone was used as negative control.

\section{Results}

\section{Chemical Characterization of EO}

Steam distillation produced a dark blue EO with a yield of $0.33 \%(\mathrm{v} / \mathrm{w})$. This preparation was analysed by GC and GC-MS in order to determine its chemical composition. The qualitative and quantitative composition determined by GC and GC-MS is given in Table 1, where the compounds are classified by phytochemical groups and listed in order of their elution on a methyl silicone HP-1 column. Forty-three compounds were identified, accounting for the $93.37 \%$ of total oil. The essential oil was dominated by the monoterpene fraction with 13 monoterpene hydrocarbons $(8.32 \%)$ and 14 oxygenated monoterpenes (57.32\%) identified. Amongst the monoterpene hydrocarbons only sabinene $(2.33 \%)$, myrcene $(2.03 \%)$ and $\gamma$-terpinene $(1.29 \%)$ ranged percentages higher than $1 \%$. In the oxygen-containing monoterpenes, $\beta$-thujone $(45.04 \%)$ followed by camphor $(6.78 \%)$ and terpinen-4-ol $(2.16 \%)$ were the main compounds.

On the other hand, in the sesquiterpene fraction $(27.13 \%)$, large amount of the sesquiterpene hydrocarbon, chamazulene $(22.71 \%$ ), and trace amount of three oxygenated sesquiterpenes (dehydro-sesquicineole, germacrene-D-4-ol and caryophyllene oxide) were found.

\section{Inhibition of Bacterial Growth}

The antibacterial activity of $A$. arborescens EO is shown in Table 2. The spectrum of inhibition was evaluated against enterobacteria, Listeria monocytogenes and salmonellas. The active extract was effective only against listerias: 34 out of 44 strains where inhibited in growth. The strains belonging to this species showed a different level of sensitivity to the treatment. L. monocytogenes ATCC $19114^{\mathrm{T}}$ resulted positive to the test, but its inhibition was low; the width of the clear area was barely $8 \mathrm{~mm}$, including diameter of paper disc $(6 \mathrm{~mm})$. The strains showing the most interesting results were L. monocytogenes 186 and 7BO, for which a clear zone of $12 \mathrm{~mm}$ diameter was detected. For the majority of sensitive strains, an average inhibition diameter of $10 \mathrm{~mm}$ was registered. Due to the strongest inhibition determined by EO against L. monocytogenes 186 and $7 \mathrm{BO}$, these two strains were further characterized for their sensitivity in terms of MIC. E. cloacae 13A was also used as negative control since it was not inhibited by EO.

L. monocytogenes 186 was found to be the most sensitive strain at both concentrations tested. EO showed an MIC of 2.5 and $1.25 \mu \mathrm{ml}^{-1}$ against strain L. monocytogenes $7 \mathrm{BO}$ at $10^{7}$ and $10^{6} \mathrm{CFU} \mathrm{ml}^{-1}$, respectively, whilst the MIC was calculated to be 1.25 and $0.625 \mu \mathrm{lml}^{-1}$ 
Table 1 Chemical composition of EO of A. arborescens (Vaill.) L. genotype growing wild in Sicily

\begin{tabular}{|c|c|c|}
\hline Chemical compounds & $\mathrm{KI}^{\mathrm{a}}$ & $\%^{\mathrm{b}}$ \\
\hline Monoterpene hydrocarbons & & 8.32 \\
\hline cis-Salvene & 856 & $\mathrm{t}$ \\
\hline$\alpha$-Thujene & 930 & $\mathrm{t}$ \\
\hline$\alpha$-Pinene & 939 & 0.70 \\
\hline Camphene & 954 & 0.61 \\
\hline Sabinene & 975 & 2.33 \\
\hline$\beta$-Pinene & 979 & $\mathrm{t}$ \\
\hline Myrcene & 990 & 2.03 \\
\hline$\alpha$-Phellandrene & 1002 & 0.34 \\
\hline$\alpha$-Terpinene & 1014 & 0.69 \\
\hline$p$-Cymene & 1024 & 0.33 \\
\hline Limonene & 1029 & $\mathrm{t}$ \\
\hline$\gamma$-Terpinene & 1054 & 1.29 \\
\hline Terpinolene & 1088 & $\mathrm{t}$ \\
\hline Oxygenated monoterpenes & & 57.32 \\
\hline 1,8-Cineole & 1031 & $\mathrm{t}$ \\
\hline cis-Sabinene hydrate & 1070 & 1.65 \\
\hline linalol & 1096 & 0.22 \\
\hline trans-Sabinene hydrate & 1098 & $\mathrm{t}$ \\
\hline$\alpha$-Thujone & 1102 & 0.75 \\
\hline$\beta$-Thujone & 1114 & 45.04 \\
\hline Menth-2-en-1-ol & 1121 & $\mathrm{t}$ \\
\hline Camphor & 1146 & 6.78 \\
\hline Borneol & 1169 & $\mathrm{t}$ \\
\hline Terpinen-4-ol & 1177 & 2.16 \\
\hline$\alpha$-Terpineol & 1188 & $\mathrm{t}$ \\
\hline Carvacrol & 1299 & $\mathrm{t}$ \\
\hline Neryl isovalerate & 1583 & $\mathrm{t}$ \\
\hline Geranyl isovalerate & 1607 & 0.72 \\
\hline Sesquiterpene hydrocarbons & & 27.13 \\
\hline$\alpha$-Copaene & 1376 & 0.19 \\
\hline$\beta$-Bourbonene & 1388 & $\mathrm{t}$ \\
\hline$\beta$-Caryophyllene & 1419 & 0.89 \\
\hline$\alpha$-Humulene & 1454 & $\mathrm{t}$ \\
\hline Germacrene-D & 1484 & 3.34 \\
\hline Bicyclogermacrene & 1500 & $\mathrm{t}$ \\
\hline$\alpha$-Farsene & 1505 & $\mathrm{t}$ \\
\hline Calacorene & 1516 & $\mathrm{t}$ \\
\hline$\delta$-Cadinene & 1523 & $\mathrm{t}$ \\
\hline Chamazulene & 1731 & 22.71 \\
\hline Oxygenated sesquiterpenes & & $\mathrm{t}$ \\
\hline Dehydro-sesquicineole- & 1471 & $\mathrm{t}$ \\
\hline Germacrene- D-4-ol & 1575 & $\mathrm{t}$ \\
\hline Caryophyllene oxide & 1583 & $\mathrm{t}$ \\
\hline Others & & 0.96 \\
\hline 6-Methyl-5-hepten-2-one & 985 & $\mathrm{t}$ \\
\hline Methyl-butyl-2-methyl hydrate & 1100 & 0.96 \\
\hline Methyl eugenol & 1403 & $\mathrm{t}$ \\
\hline
\end{tabular}

Table 1 continued

\begin{tabular}{lll}
\hline Chemical compounds & $\mathrm{KI}^{\mathrm{a}}$ & $\%^{\mathrm{b}}$ \\
\hline Total & & 94.87
\end{tabular}

${ }^{\text {a }} K I$ Kovats retention index relative to $\mathrm{C}_{8}-\mathrm{C}_{32} n$-alkanes

b Percentage of each compound on the total oil (computed from the total GC peak area)

against strain L. monocytogenes 186 at $10^{7}$ and $10^{6} \mathrm{CFU} \mathrm{ml}^{-1}$, respectively.

\section{Discussion}

Plant-derived EOs enjoy a "natural" status and, for this reason, are generally recognized as safe by consumers, which accept well their use for food preservation purposes. Due to their antimicrobial potential, EOs are considered with attention by the food scientists. Furthermore, also the interest of the food industries is on the increase, thanks to the consumer demand for effective natural products. However, it became evident that EOs cannot be employed inappropriately, because of their adverse consequences for humans, e.g. some EOs are characterized by cancer-causing effects [34]. Hence, the evaluation of their safety constitutes an important point for the future application of EOs. Studies on human voluntaries and sensory evaluation by panels of experts are needed in order to test the safety of the plant-derived molecules and their acceptability by consumers. These operations are time-consuming and difficult to realize; thus, before any other evaluation, it is fundamental to test the efficacy of the new natural compounds with supposed antibacterial properties at least against the major food pathogens.

A. arborescens is widespread in Sicily, where it grows spontaneously. The chemical analysis of EO of plants collected within Palermo province (North-western Sicily) revealed that this species elaborated an essential oil rich in $\beta$-thujone (45.04\%) and chamazulene $(22.71 \%)$. The main compound, thujone, is an oxygenated monoterpene commonly found in spice and medicinal plants such as sage (Salvia officinalis L.), clary sage (Salvia sclarea L.), wormwood (Artemisia absinthium L.) and tansy (Tanacetum vulgaris L.). Thujone is present in some alcoholic beverages, but the isomer $\beta$-thujone is claimed to be toxic for human consumption [16, 35]. Thus, the use of thujone undergoes several restrictions, although the average intake by consumers is about 100 times lower than the NOEL (noobserved-effect level) derived from a 14-week study in rats [16]. Chamazulene, the second most abundant compound in A. arborescens EO, is a sesquiterpene hydrocarbon, characteristic of several plants of Asteraceae family, such 
Table 2 Inhibitory activity of A. arborescens EO

\begin{tabular}{|c|c|c|}
\hline Bacterial species & Strain (inhibition) & Source of isolation \\
\hline E. amnigenus & DHPS70B3(-) & Freeze-dried chicken \\
\hline E. amnigenus & DHPS60A2(-) & Freeze-dried lamb \\
\hline E. cloacae & DHPS24(-), DHPS25(-) & Milk powder \\
\hline E. cloacae & DHPS13A(-) & Multi-cereal cream \\
\hline E. cloacae & DHPS62A(-) & Freeze-dried chicken \\
\hline E. cloacae & DHPS $32 \mathrm{~A}(-)$ & Milk flour \\
\hline E. cloacae & DHPS43B1(-) & Semolina \\
\hline E. hormaechei subsp. steigerwaltii & $\begin{array}{l}\text { DHPS1(-), DHPS2(-), DHPS6(-), DHPS7(-), } \\
\text { DHPS8(-), DHPS11(-), DHPS13 (-), DHPS15(-), } \\
\text { DHPS19(-), DHPS31(-) }\end{array}$ & Milk powder \\
\hline E. sakazaki & DHPS2B(-) & Rice cream \\
\hline E. sakazaki & DHPS23A(-) & Green rice cream \\
\hline L. monocytogenes & ATCC $19114^{\mathrm{T}}(+)$ & Animal tissue \\
\hline L. monocytogenes & $\begin{array}{l}\text { DHPS129(+), DHPS130(+), DHPS131(+), } \\
\text { DHPS132(-), DHPS133(-), DHPS134(-), } \\
\text { DHPS135 (+), DHPS136(+), DHPS137(+), } \\
\text { DHPS138(+), DHPS139(+), DHPS140(+) }\end{array}$ & Human \\
\hline L. monocytogenes & DHPS179(+) & Salmon \\
\hline L. monocytogenes & DHPS180(+), DHPS182(+) & Ricotta cheese \\
\hline L. monocytogenes & DHPS184(-) & Rice salad \\
\hline L. monocytogenes & DHPS185(-) & Beef \\
\hline L. monocytogenes & DHPS186(++) & Mozzarella salad \\
\hline L. monocytogenes & DHPS187(+) & Roasted chicken \\
\hline L. monocytogenes & DHPS188(+) & Green salad \\
\hline L. monocytogenes & DHPS1BO $(+)$, DHPS10BO $(+)$ & Chopped meat \\
\hline L. monocytogenes & DHPS2BO $(+)$, DHPS 3BO $(+)$ & Fresh salami \\
\hline L. monocytogenes & DHPS4BO $(+)$, DHPS5BO $(+)$ & 3-week ripened salami \\
\hline L. monocytogenes & DHPS6BO $(+)$, DHPS7BO $(++)$, DHPS8BO $(-)$ & 4-week ripened salami \\
\hline L. monocytogenes & DHPS11BO(+) & Meat factory surfaces \\
\hline L. monocytogenes & DHPS12BO(+) & 1-week ripened salami \\
\hline L. monocytogenes & $\begin{array}{l}\text { DHPS13BO }(+), \text { DHPS14BO }(-), \text { DHPS15BO }(-), \\
\text { DHPS16BO }(-), \text { DHPS7BO }(+), \text { DHPS18BO }(+), \\
\text { DHPS19BO(+), DHPS20BO(+), DHPS21BO }(-)\end{array}$ & Gorgonzola cheese \\
\hline L. monocytogenes & DHPS22BO(+), DHPS23BO(+), DHPS24BO(+) & Taleggio cheese \\
\hline Salmonella Abony & DHPS50398(-) & Human \\
\hline Salmonella Agona & DHPS50361(-) & Human \\
\hline Salmonella Blockley & DHPS50314(-) & Human \\
\hline Salmonella Bredeney & DHPS50374(-) & Human \\
\hline Salmonella Derby & DHPS50399(-) & Human \\
\hline Salmonella Enteritidis & DHPS50339(-), DHPS50430(-), DHPS50371(-) & Human \\
\hline Salmonella Hadar & DHPS50272(-) & Human \\
\hline Salmonella Infantis & DHPS50356(-) & Human \\
\hline Salmonella Muenchen & DHPS50393(-) & Human \\
\hline Salmonella Napoli & DHPS50376(-) & Human \\
\hline Salmonella Newport & DHPS50404(-) & Human \\
\hline Salmonella Panama & DHPS50347(-) & Human \\
\hline Salmonella Saintpaul & DHPS50415(-) & Human \\
\hline Salmonella Thompson & DHPS50280(-) & Human \\
\hline Salmonella Typhimurium & DHPS50414(-), DHPS 50384(-) & Human \\
\hline Salmonella Typhimurium & DHPS50432(-) & Seafood \\
\hline Salmonella Veneziana & DHPS50391(-) & Human \\
\hline
\end{tabular}

- , no inhibition; + , clear inhibition ( $8-10 \mathrm{~mm}$ diameter); ++ , strong inhibition $(>10 \mathrm{~mm}$ diameter)

The culture collections are as follows: DHPS Department of Health Promotion Sciences "G. D'Alessandro" (Palermo, Italy); ATCC American Type Culture Collection (Manassa, VA, USA) 
as chamomile and achillea. Indeed, it is an artefact molecule obtained from the precursore prochamazulene contained in plants' tissues $[18,46]$ during steam distillation. Chamazulene possesses interesting anti-inflammatory properties [41], and for this reason it has a relevant industrial importance. Our results showed that EO of A. arborescens growing wild within Palermo province is characterized by high concentrations of both compounds.

So far, A. arborescens plants examined for these characters have been divided into two chemotypes, high producers of thujone or high producers of chamazulene. It was also supposed that the biochemical process for the generation of thujone is in competition with that for the production of chamazulene [39]. Thus, this aspect deserves a deeper investigation. However, previous studies carried out on the chemical characterization of A. arborescens EO reported a different number of compounds identified, from 21 to 82 [1, 32]. Although chamazulene followed by camphor dominated the EO of plants collected in different areas of South Italy [32], the main compounds recognized from this species collected in the Algerian maritime littoral were the same (chamazulene and $\beta$-thujone), with similar high concentrations, found in our study. Thus, a third A. arborescens chemotype, dealing with high concentration of both $\beta$-thujone and chamazulene, might be proposed, even though other studies are needed to support this hypothesis. It is well known that geographical origin, environmental factors and the stage of plant development, as well as day and night duration, can affect the qualitative/quantitative composition of the oils $[24,36]$. Moreover, the results of our study, compared with those previously published by Lo Presti et al. [32], which included also plants collected in Sicily, highlight the observations that different chemotypes may cohabit in restricted geographical areas.

In view of the possible future food application of A. arborescens EO, as natural alternative to traditional chemical additives, the antimicrobial activity of this mixture of chemical compounds has been evaluated. The inhibitory spectrum was evaluated against bacterial species (Enterobacteria, L. monocytogenes and salmonellas) responsible for human outbreaks commonly associated with food matrices [9, 22, 44]. All Gram-negative species (Salmonella spp. and Enterobacter spp.) used as test organisms were insensitive to the EO assayed. However, interestingly enough inhibition was observed with several strains of the food-borne pathogen $L$. monocytogenes, the only Gram-positive species used in this study. Also in other studies Gram-positive bacteria were found to be more susceptible to EO and various solvent extracts than Gramnegative bacteria $[4,6,10]$. This effect is related to the presence of an outer membrane on Gram-negative bacteria, which provides a strong impermeable barrier [37].
L. monocytogenes if often reported to be susceptible to EOs [12].

The highest inhibition was obtained with strains $L$. monocytogenes 186 and 7BO, both of food origin (mozzarella salad and ripened salami, respectively). This species has a ubiquitous nature and it is characterized by hardiness. Unlike many pathogens, L. monocytogenes survives to the food-processing technologies that rely on acidic or salty conditions [23], and shows a strong ability to multiply, although slowly, at low temperatures; thus, it may be found even in properly refrigerated foods. For all these reasons, this bacterium constitutes a relevant risk for consumers' health and its control by means of natural strategies is desirable. Several components of A. arborescens EO, including caryophyllene, caryophyllene oxide, $\alpha$-humulene and germacrene-D, have been reported as important components of various EOs with enormous potential to inhibit microbial pathogens $[15,45,48]$.

The above strains L. monocytogenes 186 and 7BO were further characterized for their sensitivity in terms of MIC. The test was carried out at two cell concentrations to determine the effect of the inoculums on the sensitivity level. The results showed that A. arborescens EO tested was active against high concentrations $\left(10^{7} \mathrm{CFU} \mathrm{ml}{ }^{-1}\right)$ of L. monocytogenes 186 , although its effect diminished with the increment of cell number.

In conclusion, the results showed by our study indicate that EO of A. arborescens is effective against L. monocytogenes, one of the major agents of food-borne illnesses; thus, it might represent a natural preservative, alternative to the common chemical additives. Works are being prepared in order to better characterize the in situ efficacy of this EO using food matrices, its suitability in active packaging strategies, and to evaluate its organoleptic acceptability by consumers, as well as its safety.

\section{References}

1. Abderrahim A, Belhamel K, Chalchat J-C, Figuérédo G (2010) Chemical composition of the essential oil from Artemisia arborescens L. growing wild in Algeria. Records Nat Prod 4:87-90

2. Adams RP (2007) Identification of essential oil components by gas chromatography/mass spectrometry. Allured Publishing Corporation, Carol Stream

3. Al-Momani W, Abu-Basha E, Janakat S, Nicholas RAJ, Ayling RD (2007) In vitro antimycoplasmal activity of six Jordanian medicinal plants against three Mycoplasma species. Trop Anim Health Prod 39:515-519

4. Al-Reza SM, Rahman A, Lee J, Kang SC (2010) Potential roles of essential oil and organic extracts of Zizyphus jujuba in inhibiting food-borne pathogens. Food Chem 119:981-986

5. Burt S (2004) Essential oils: their antibacterial properties and potential application in foods-a review. Int J Food Microbiol 94:223-253 
6. Calsamiglia S, Busquet M, Cardozo PW, Castillejos L, Ferret A (2007) Invited review: essential oils as modifiers of rumen microbial fermentation. J Dairy Sci 90:2580-2595

7. Carrubba A, Calabrese I (1998) Antioxidant compounds in some herbaceous aromatic plants. Acta Hortic 457:85-93

8. Carrubba A, Catalano C (2009) Essential oil crops for sustainable agriculture - a review. In: Lichtfouse E (ed) Climate change, intercropping, pest control and beneficial microorganisms. Springer Science + Business Media, Dijon, pp 137-188

9. Crum-Cianflone NF (2008) Salmonellosis and the gastrointestinal tract: more than just peanut butter. Curr Gastroenterol Rep 10: 424-431

10. Davidson PM, Naidu AS (2000) Phyto-phenols. In: Naidu AS (ed) Natural food antimicrobial systems. CRC Press, Boca Raton, pp 265-293

11. Dessì MA, Deiana M, Rosa A, Piredda M, Cottiglia F, Bonsignore L, Deidda D, Pompei R, Corongiu FP (2001) Antioxidant activity of extracts from plants growing in Sardinia. Phytother Res 15:511-518

12. Di Pasqua R, De Feo V, Villani F, Mauriello G (2005) In vitro antimicrobial activity of essential oils from Mediterranean Apiaceae, Verbenaceae and Lamiaceae against foodborne pathogens and spoilage bacteria. Ann Microbiol 55:139-143

13. Drevets DA, Bronze MS (2008) Listeria monocytogenes: epidemiology, human disease, and mechanisms of brain invasion. FEMS Immunol Med Microbiol 53:151-165

14. Dudain N, Poljakoff-Mayber A, Mayer AM, Putievsky E, Lerner HR (1999) Essential oils as allelochemicals and their potential use as bioherbicides. J Chem Ecol 25:1079-1089

15. El-Sakhawy FS, El-Tantawy ME, Ross SA, El-Sohly MA (1998) Composition and antimicrobial activity of the essential oil of Murraya exotica L. Flav Fragr J 13:59-62

16. European Commission (2003) Opinion of the scientific committee on food on Thujone. Expressed on 2nd Dec 2002. European Commission-Health and Consumer Protection DirectorateGeneral, Scientific Committee on Food-SCF/CS/FLAV/FLAVOUR/23 ADD2 Final, 6 February 2003

17. Farber JM (2000) Present situation in Canada regarding Listeria monocytogenes and ready-to-eat seafood products. Int $\mathrm{J}$ Food Microbiol 62:247-251

18. Franz C, Novak J (2010) Sources of essential oils. In: Baser KHC, Buchbauer G (eds) Handbook of essential oils: science technology and applications. CRC Press, Boca Raton, pp 39-81

19. Garcia S, Garnatje T, Twibell JD, Vallès J (2006) Genome size variation in the Artemisia arborescens complex (Asteraceae, Anthemideae) and its cultivars. Genome 49:244-253

20. Goulet V, Hedberg C, Le Monnier A, de Valk H (2008) Increasing incidence of listeriosis in France and other European countries. Emerg Infect Dis 14:734-740

21. Haraguchi H (2001) Antioxidative plant constituents. In: Tringali C (ed) Bioactive compounds from natural sources isolation characterisation and biological properties. Taylor \& Francis, London, pp 337-377

22. Healy B, Cooney S, O'Brien S, Iversen C, Whyte P, Nally J, Callanan JJ, Fanning S (2010) Cronobacter (Enterobacter sakazakii): an opportunistic food-borne pathogen. Foodborne Pathog Dis 7:339-350

23. Jacobson L (2008) Listeriosis. Pediatr Rev 29:410-411

24. Jerkovich I, Mastelic M, Milos M, Juteau F, Masotti V, Viano J (2003) Chemical variability of Artemisia vulgaris L. essential oils originated from the Mediterranean area of France and Croatia. Flav Fragr J 18:436-440

25. Karapinar M, Aktug SE (1987) Inhibition of foodborne pathogens by thymol, eugenol, menthol and anethole. Int J Food Microbiol 4:161-166
26. Kelmanson JE, Jager AK, Van Staden J (2000) Zulu medicinal plants with antibacterial activity. J Ethnopharmacol 69:241-246

27. Khan R, Islam B, Akram M, Shakil S, Ahmad A, Ali SM, Siddiqui M, Khan AU (2009) Antimicrobial activity of five herbal extracts against multi drug resistant (MDR) strains of bacteria and fungus of clinical origin. Molecules 14:586-597

28. Kordali S, Cakir A, Mavi A, Kilic H, Yildirim A (2005) Screening of chemical composition and antifungal and antioxidant activities of the essential oils from three Turkish Artemisia Species. J Agric Food Chem 53:1408-1416

29. Lai F, Wissing SA, Müller RH, Fadda AM (2006) Artemisia arborescens $\mathrm{L}$ essential oil-loaded solid lipid nanoparticles for potential agricultural application: preparation and characterization. AAPS PharmSciTech, 7 (1) Article 2 http://www.aapspharm scitech.org

30. Lai F, Loy G, Manconi M, Manca ML, Fadda AM (2007) Artemisia arborescens $\mathrm{L}$ essential oil loaded beads: preparation and characterization. AAPS PharmSciTech, 8 (3) Article 67 http:// www.aapspharmscitech.org

31. Lopes-Lutz D, Alviano DS, Alviano CS, Kolodziejczyk PP (2008) Screening of chemical composition, antimicrobial and antioxidant activities of Artemisia essential oils. Phytochemistry 69:1732-1738

32. Lo Presti M, Crupi ML, Zellner B, Dugo G, Mondello L, Dugo P, Mondello L, Dugo P, Ragusa S (2007) Characterization of Artemisia arborescens L. (Asteraceae) leaf-derived essential oil from Southern Italy. J Essent Oil Res 19:218-224

33. Marongiu B, Piras A, Porcedda S (2010) Comparative analysis of the oil and supercritical $\mathrm{CO}_{2}$ extract of Artemisia arborescens $\mathrm{L}$. and Helichrysum splendidum (Thunb.) Less. Nat Prod Res 20: 421-428

34. McGuffin M, Hobbs C, Upton R, Goldberg A (1997) American herbal products association's botanical safety handbook. CRC Press, Boca Raton

35. National Toxicology Program (2010) Testing status of agents at NTP (US National Toxicology Program-Department of Health and Human Services) Alpha-Thujone; alpha/beta-Thujone mixture. US. http://ntp.niehs.nih.gov/go/TSM980059; http://ntp. niehs.nih.gov/go/TSM990011. Last accessed 16 July 2010

36. Nguyen TPT, Nguyen TT, Tran MH, Tran HT (2004) Artemisia vulgaris $\mathrm{L}$. from Vietnam: chemical variability and composition of the oil along the vegetative life of the plant. J Essent Oil Res $16: 358-361$

37. Nikaido H (1994) Prevention of drug access to bacterial targets: permeability barriers and active efflux. Science 264:382-388

38. Nychas GJE, Tassou CC, Skandamis P (2003) Antimicrobials from herbs and spices. In: Roller SM (ed) Natural antimicrobials for the minimal processing of foods. Woodhead Publishers, CRC Press, New York, pp 176-200

39. Pappas R, Sheppard-Hanger S (2000) Artemisia arborescensessential oil of the Pacific Northwest: a high-chamazulene, lowthujone essential oil with potential skin-care applications. http://atlanticinstitute.com/artemisia.pdf

40. Pignatti S (1982) Flora d'Italia. Edagricole, Bologna

41. Salamon I (2009) Chamomile biodiversity of the essential oil. Qualitative-quantitative characteristics. In: Sener B (ed) Innovations in chemical biology. Springer Science + Business Media, Dordrecht, pp 83-90

42. Settanni L, Corsetti A (2008) Application of bacteriocins in vegetable food biopreservation. Int $\mathrm{J}$ Food Microbiol 121: $123-138$

43. Sinico C, De Logu A, Lai F, Valenti D, Manconi M, Loy G, Bonsignore L, Fadda AM (2005) Liposomal incorporation of Artemisia arborescens L. essential oil and in vitro antiviral activity. Eur J Pharm Biopharm 59:161-168 
44. Swaminathan B, Gerner-Smidt P (2007) The epidemiology of human listeriosis. Microb Infect 9:1236-1243

45. Tewtrakul S, Yuenyongsawad S, Kummee S, Atsawajaruwan L (2005) Chemical components and biological activities of volatile oil of Kaempferia galanga Linn. Songklanakarin J Sci Technol 27:503-507

46. Wagner C, Friedt W, Marquard RA, Ordon F (2005) Molecular analyses on the genetic diversity and inheritance of $(-)-\alpha$ - bisabolol and chamazulene content in tetraploid chamomile (Chamomilla recutita (L.) Rausch.). Plant Sci 169:917-927

47. Xu HX, Lee SF (2001) Activity of plant flavonoids against antibiotic-resistant bacteria. Phytother Res 15:39-43

48. Yuenyongsawad S, Tewtrakul S (2005) Essential oil components and biological activities of Coleus parvifolius leale. Songklanakarin J Sci Technol 27:497-502 